\title{
Mechanical properties of cryolite from Ivigtut, South Greenland
}

\author{
HANS PAULY
}

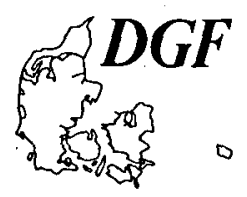

Pauly, H.: Mechanical properties of cryolite from Ivigtut, South Greenland. Bull. geol. Soc. Denmark, Vol. 33, pp. 401-413, Copenhagen, February, 28th, 1985.

\begin{abstract}
Cryolite made up about 75 per cent of the deposit in Ivigtut, South Greenland. Its mechanical properties seem important for the shaping and for the internal build-up of the deposit of which a major part, sideritecryolite with about 15 per cent siderite and a few per cent of sulphides, quartz etc., consolidated between 500 and $600^{\circ} \mathrm{C}$.

Thermal expansion, by volume, of cryolite is shown to be two to five times greater than the expansion of the accompanying minerals and rocks. The elastic constants of cryolite are found to be: $E=6.8 \cdot 10^{5}$ bars, $G=2.7 \cdot 10^{5}$ bars and Poisson's No. $=0.24$. Compressive strength at room temperature 919 bars.

Uniaxial compression tests at atmospheric pressure showed strength to increase to 1360 bars at $200^{\circ} \mathrm{C}$ and strain rate $0.05 \mathrm{~mm}$ per minute. Cryolite behaved in the tests up to $300^{\circ} \mathrm{C}$ as a brittle substance. Ductility was noted at temperatures from $400^{\circ} \mathrm{C}$ and, depending on strain rate, cryolite was found to exhibit unrestricted plastic deformations above $450^{\circ} \mathrm{C}$. Ductility of cryolite around $500^{\circ} \mathrm{C}$ was found to be about the same as found for halite, tested in the same instrument, at $150-200^{\circ} \mathrm{C}$.

It is to be noted that the plastic deformation observed in these uniaxial compression tests dominantly appeared as bending of lamellae developed parallel to the load axis both in cryolite and in halite.

In the siderite-cryolite, representing the earliest formed part of the deposit, siderite exhibits a pronounced cataclastic structure. This is attributed to the high ductility of cryolite at temperatures around $500^{\circ} \mathrm{C}$.

The contraction on cooling of cryolite appears important in judging joint patterns of the intrusion as well as macro- and microfissures within the deposit.
\end{abstract}

Hans Pauly, Technical University of Denmark, bg. 204, Lyngby, 2800 Denmark. December 12th, 1983.

\section{Introduction}

The cryolite deposit at Ivigtut, South Greenland, was located in the exposed roof zone of a small granite stock $270 \mathrm{~m}$ across which was emplaced at levels corresponding to a load pressure of 1-2 kbar, Bailey 1980.

Cryolite with about $15 \%$ siderite, a few per cent quartz and a few per cent sulphides made up $3 / 4$ of a flattened, lens-shaped body, about $170 \mathrm{~m}$ in diameter and up to $70 \mathrm{~m}$ high. Its western and lower part had a shell of cryolite mixed with fluorite, topaz etc. Intercalated between this shell of fluorite-cryolite and the main mass of the lens, the siderite-cryolite, quarrying revealed around the year 1900 the presence of a considerable mass of pure, white, coarse grained cryolite about $\mathbf{1 5 0}$ $\mathrm{m}$ long, $40 \mathrm{~m}$ wide and $30 \mathrm{~m}$ thick. Further details with a map and a longitudinal section through the cryolite deposit is given in Karup-Møller \& Pauly 1979.

The siderite-cryolite consolidated at temperatures between 500 and $600^{\circ} \mathrm{C}$, Pauly 1960 . Ac- cording to Oen \& Pauly 1967, siderite formation at these temperatures seems to demand a rather high partial pressure of $\mathrm{CO}_{2}$ i.e. the fluid pressure in the earlier stages of mineralisation was probably in excess of load pressure. The relations between siderite-cryolite and fluorite-cryolite indicate that the latter consolidated later. Sulphide parageneses belonging to the fluorite-cryolite seem to have consolidated between 300 and $200^{\circ} \mathrm{C}$, Karup-Møller 1973. The intercalated mass of pure cryolite apparently formed at temperatures between those relevant to the two other units of the deposit.

Cryolite appeared as a matrix for the accompanying minerals in the greater part of the lens shaped deposit. This is particularly clear for cryolite in the siderite-cryolite. The behavior of cryolite may therefore have played an important role both in the shaping of the deposit and in the development of structures and textures within the deposit. The salt-like character of the mineral cryolite suggests the possibility that it has mechanical properties comparable to halite, i.e. the 
ability to flow plastically. Pauly 1982 found it likely that plastic deformation of cryolite contained the clue to the formation of breccias where pure cryolite cements rock xenoliths which show no signs of chemical reaction rims towards the cryolite. It was assumed that the plasticity characteristics of cryolite are intermediate between those of halite and fluorite or calcite.

Strength and ductility tests to elucidate the properties of cryolite would have to be performed under conditions relevant to the formation of the deposit in Ivigtut i.e. temperatures up to $500-600^{\circ} \mathrm{C}$ and confining pressures around 2 kbars. The available experimental equipment only allowed uniaxial compression tests at atmospheric pressure. In judging the results obtained it is, however, worth noting that confining pressure enhances both ultimate strength and ductility (Hardin 1966). Incidentally his work reports on two tests on cryolite at $24^{\circ} \mathrm{C}$ and at a confining pressure of 5000 bars which Dr. Handin was kind enough to perform for the present author a couple of years ago. A summary of the results will be given below.

The thermal expansion, or rather the contraction on cooling, of cryolite and the other minerals constituting the deposit becomes of interest in the evaluation of the mutual relations of the minerals, the development of microfissures within the single minerals and macrofissures transecting the units of the deposit as well as the border relations of the deposit towards the rocks of the surrounding intrusion.

Before entering upon these various mechanical properties of cryolite it is necessary to recapitulate the main crystallographical properties of the mineral.

\section{Crystallographic properties of cryolite}

Cryolite, $\mathrm{Na}_{3} \mathrm{~A}_{1} \mathrm{~F}_{6}$, monoclinic, $\mathrm{P}_{1} / \mathrm{m}$, is pseudocubic in appearance. The transformation $1 \overline{1} 0 / 110 /$ 001 leads the cryolite lattice over into a quasi-cubic "double lattice" so termed because its cell has twice the volume of the cell in the true cryolite lattice (Donnay 1952). On heating it inverts to a true cubic modification (Mügge 1908 ) at $560^{\circ} \mathrm{C}$ (Holm 1965). Steward \& Rooksby 1953 investigated the structure of $\beta$-cryolite.

Cryolite is invariably twinned. Theoretically 13 different twin laws are possible (Donnay 1952) reflecting the 13 independent symmetry elements which with those of the monoclinic crystal constitute the complete cubic symmetry (Wrinch 1952). Bøggild 1912 showed 8 of these twin laws to be present in cryolite from Ivigtut. In freely developed crystals, lining fissures in cryolite, 4 of the laws were found; 3 of these may have formed during growth $[110]^{90},[110]$ and [111]. In the pure white, coarse grained cryolite 7 twin laws were observed: $[110]^{90},[110],[021]^{120},(001),(100)$, (112) and (112), see also Pauly 1978. It should be noted that the first and the third of these laws interchange the faces of $\{110\}$ and $\{001\}$ which in the "double lattice" correspond to the quasicube.

On heating to temperatures about the inversion temperature the birefringence of cryolite gradually disappears leaving the mineral optically isotropic (Bøggild 1912). On heating cryolite Steward \& Rooksby 1953 noted: between 500 and $550^{\circ} \mathrm{C}$ the departure from a cubic arrangement became rapidly smaller and at $550^{\circ} \mathrm{C}$ the lines of the powder photograph fell precisely in the sequence demanded by a cubic space group. Yurk et al. 1973 reported that twinning and birefringence gradually disappeared when the mineral was heated between 470 and $520^{\circ} \mathrm{C}$.

Fragments of the freely developed crystals after heating to near disappearance of birefringence were observed by Bøggild 1912, to be transected by relatively few, regular twin lamellae identified by goniometer measurements to represent $[110],[110]^{90}$, and $[021]^{120}$. The first two may as mentioned also be formed by growth. They can, with difficulty, be produced mechanically at room temperature. Bøggild observed this on crystals accidentally broken during examination. The rarity of such crystals prevented him from undertaking more than a few experiments of this kind. The pure, white, coarsegrained cryolite was observed in the quarry to occur as individuals up to $6 \mathrm{~m}$ (Bøggild 1905). The grain size was commonly of $\mathrm{dm}$ sizes. Broken pieces were often bounded by 3 mutually nearly perpendicular, plane surfaces. Two of these represent a strong parting along the prism faces (Bøggild 1912). The third, less well developed fracture plane may reflect a fair cleavage along (001) (Pauly 1978).

The density of cryolite at room temperature is 
2.973 as calculated from the X-ray data of Hawthorne \& Ferguson 1975. Cryolite from Ivigtut was shown to melt at $1013.5 \pm 0.3^{\circ} \mathrm{C}$ (Landon \& Ubbelohde 1957).

\section{Thermal expansion of Cryolite}

Cryolite expands $14 \%$ when heated to the melting point; on melting it expands a further $25 \%$ (Landon \& Ubbelohde 1957). The cubic modification has a unit cell (Steward \& Rooksby 1953), whose volume is $7.2 \%$ larger than the corresponding double cell at room temperature (Hawthorne \& Ferguson 1975). The volume of the unit cell at $625^{\circ} \mathrm{C}$, Holm \& Holm 1970, is $7.8 \%$ larger than the double cell at room temperature.

The data for cryolite have been plotted together with data from Skinner 1966 for minerals occurring together with cryolite. Data for $\mathrm{NaCl}$ and for calcite have been included for comparison (fig. 1).

It is seen that cryolite on cooling from $560^{\circ} \mathrm{C}$ contracts twice as much as galena and quartz, five times as much as sphalerite and seven times as much as topaz. No data were available for siderite but if its contraction on cooling is similar to that of calcite it should be comparable with sphalerite.

\section{Stress strain relationship of cryolite at $24^{\circ} \mathrm{C}$ and 5000 bars confining pressure}

Two $\mathrm{cm}$-sized samples of the white coarsegrained cryolite from Ivigtut have been tested at $\mathbf{5 0 0 0}$ bars confining pressure at room temperature (Handin 1966). One brass jacketed sample was subjected to compression the other to elongation.

In the compression test the following strain (in $\%)$ and stress (differential stress in bars) values were recorded: $1 \%-1180,2 \%-3840,5 \%-$ $3630,10 \%-3470$ and $42.1 \%-3840$. In the elongation test the following values were recorded: $1 \%-1890,2 \%-3180,5 \%-4470,10 \%-4770$ and $21.2 \%-5120$. Both tests terminated before rupture with the stress-strain curves still rising.

When the jackets were opened both samples were found to have changed from white to a light

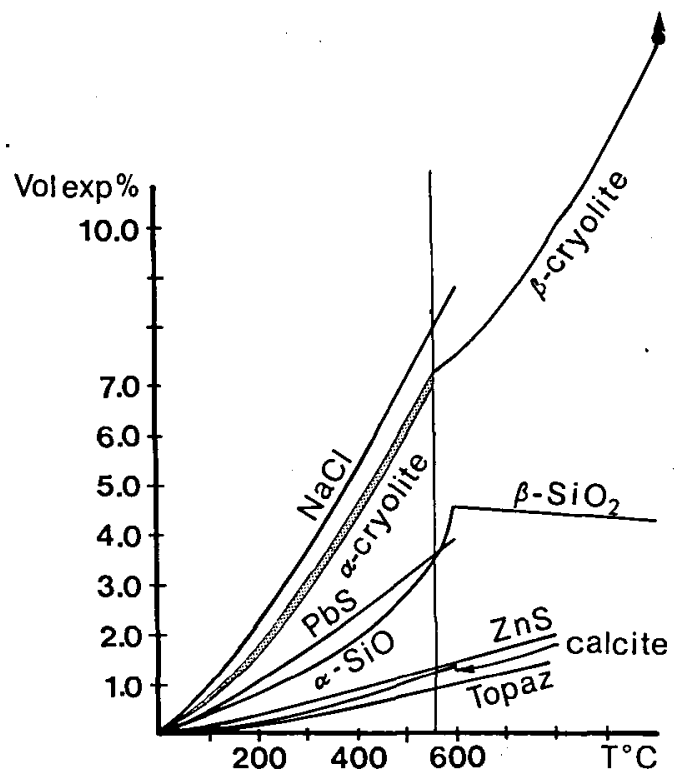

Fig. 1. Volume expansion of cryolite as percentage change of volume at room temperature. For comparison values for halite, calcite and some minerals accompanying cryolite are plotted after Skinner 1966.

purple colour. This colour is still preserved 24 years later. Activation of colour centers through the plastic deformation of the samples seems to explain the phenomenon. Cryolite is known to take such a colour in the immediate surroundings of dynamite charges used in blastings in the mine. The left over parts of drill holes for blasting showed this colour in the cryolite up to about 15 $\mathrm{cm}$ from the drill hole in the bottom part of the hole where the charge was placed. The colour disappears if the cryolite sample is heated to a few hundred degrees. Another colour mechanism in cryolite is triggered by irradiation; cryolite surrounding minerals with radioactive elements is smoky to nearly black. The smoky cryolite also aquires the purple colour in the vicinity of blasting charges (Pauly 1962).

\section{Elasticity constants and compressive strength of cryolite at $24^{\circ} \mathrm{C}$ and atmospheric pressure}

Dynamic elasticity constants determined by the resonance frequency method, Pickett 1945, are summarized in table 1 from unpublished reports 
Table 1. Dynamic elasticity constants for cryolite at room temperature, determined by the Resonance Frequency Method, by Erik Truds $\varnothing$, M.Sc.

\begin{tabular}{|c|c|c|c|c|c|c|c|}
\hline & $\begin{array}{c}\text { Sample } \\
\text { Dimensions } \\
\text { in } \mathrm{cm}\end{array}$ & $\begin{array}{l}\text { Weight } \\
\text { in } \mathrm{kg}\end{array}$ & $\begin{array}{l}\text { Density } \\
\mathrm{g} / \mathrm{cm}^{3}\end{array}$ & $\begin{array}{l}E_{b} \\
\text { bar } \\
\times 10^{5}\end{array}$ & $\begin{array}{c}\mathrm{E}_{1} \\
\text { bar } \\
\times 10^{5}\end{array}$ & $\begin{array}{c}\text { G } \\
\text { bar } \\
\times 10^{5}\end{array}$ & $\begin{array}{l}\text { Pois- } \\
\text { son's } \\
\text { No. v }\end{array}$ \\
\hline 1 & $23.83 \times 4.00 \times 4.00$ & 1.129 & 2.961 & $\begin{array}{c}6.74 \\
(3129)\end{array}$ & $\begin{array}{c}6.82 \\
(9945)\end{array}$ & $\begin{array}{c}2.75 \\
(5812)\end{array}$ & 0.23 \\
\hline 2 & $26.15 \times 8.97 \times 8.84$ & 6.126 & 2.954 & $\begin{array}{c}6.78 \\
(4855)\end{array}$ & $\begin{array}{c}6.82 \\
(9100)\end{array}$ & $\begin{array}{c}2.77 \\
(5327)\end{array}$ & 0.23 \\
\hline 3 & $24.12 \times 8.88 \times 8.84$ & 5.577 & 2.956 & $\begin{array}{c}7.00 \\
(5578)\end{array}$ & $\begin{array}{c}7.10 \\
(10095)\end{array}$ & $\begin{array}{c}2.81 \\
(5832)\end{array}$ & 0.24 \\
\hline 4 & $23.90 \times 5.89 \times 5.67$ & 2.345 & 2.938 & $\begin{array}{c}6.17 \\
(3930)\end{array}$ & $\begin{array}{c}6.27 \\
(9570)\end{array}$ & $\begin{array}{c}2.49 \\
(5547)\end{array}$ & 0.25 \\
\hline
\end{tabular}

Poisson's No: $v=\frac{E}{2 G}-1$

Numbers in parenthesis = fundamental frequency in $\mathrm{kHz}$.

Density of cryolite from X-ray data: 2.973 .

Table 2. Compressive strength, static and dynamic elasticity constants for cryolite at room temperature, by P. Nepper-Christensen, M.Sc.

\begin{tabular}{lcccccc}
\hline $\begin{array}{c}\text { Sample } \\
\text { Dimensions } \\
\text { in cm }\end{array}$ & $\begin{array}{c}\mathrm{E} \\
\text { static } \\
\text { bar } \times 10^{5}\end{array}$ & $\begin{array}{c}\mathrm{E} \\
\text { dynamic } \\
\text { bar } \times 10^{5}\end{array}$ & $\begin{array}{c}G \\
\text { static } \\
\text { bar } \times 10^{5}\end{array}$ & $\begin{array}{c}\text { Poisson's } \\
\text { No. v }\end{array}$ & $\begin{array}{c}\text { Compressive } \\
\text { strength } \\
\text { in bars }\end{array}$ \\
\hline $3 a$ & $15.9 \times 8.9 \times 8.8$ & 6.5 & 7.1 & 2.6 & 0.24 & 919 \\
$4 a$ & $21.6 \times 5.9 \times 5.6$ & 6.7 & 6.27 & 2.7 & 0.24 & 753 \\
5 & $3.0 \times 1.46 \times 1.46$ & 6.7 & - & 2.7 & 0.23 & 900 \\
\hline
\end{tabular}

E-dynamic calculated from $E=d \cdot v^{2}, d=$ density and $v=$ sound velocity; frequency used was about $60 \mathrm{kHz}$.

$G$ calculated from $G=\frac{E}{2(1+v)}$

Samples 3a and $4 a$ are the same as No. 3 and 4 in Table 1, but shortened.

by Mr. E. Trudsø 1957 and 1961 to the present author. The low values for $E$ and $G$ of sample No. 4 are probably due to specific weaknesses of this sample; its low density and the low strength reported for this sample from the following experiment, see table 2, support this assumption. Samples 1, 2 and 3 gave as average values $E_{b}=$ $6.84 \cdot 10^{5}$ bars from bending vibrations, $\mathrm{E}_{1}=6.91$ - $10^{5}$ bars from longitudinal vibrations and $\mathrm{G}=$ $2.78 \cdot 10^{5}$ bars from torsional vibrations. Calculations gave Poisson's No. $=0.24$.

Samples 3 and 4, trimmed so as to have a better shape, together with some small-sized samples were examined in a series of compression tests. On the two first samples E-dynamic was de- termined from sound velocity measurements. In the compression tests the samples were subjected to stepwise loading and the strains were registered by strain gauges placed on the vertical sides of the samples, parallel with and perpendicular to the load axis. The results obtained are summarized in table 2 from an unpublished report by $\mathrm{Mr}$. P. Nepper-Christensen 1968 to the present author. It is interesting to note the closeness, of these values to those determined in the first experiment. The recorded stress-strain curves were virtually straight lines right up to the point of fracture where the recorded strains were about $0.14 \%$ with a compressive strength of about 900 bars. 


\section{Uniaxial compression of cryolite at temperatures up to $550^{\circ} \mathrm{C}$ and . atmospheric pressure}

The test specimens, $15 \times 10 \times 10 \mathrm{~mm}$, were cut from samples of the white, pure, coarse grained cryolite so that the sides of the prisms were parallel to the parting faces of the cryolite (110), (110) and (001). The square end faces were rubbed with $\mathrm{MoS}_{2}$-powder in order to reduce friction. The specimens were generally heated to 300 $400^{\circ} \mathrm{C}$ before testing in order to eliminate frail specimens. The first batch cut from one large cryolite block gave an $80 \%$ recovery or nearly 50 specimens whereas in later batches cut from other blocks the recovery was only about $10 \%$. This was presumably due to variations in the content of vacuoles of the various blocks of cryolite.

The specimens were placed in the bore, $30 \mathrm{~mm}$ across, of a steel cylinder $70 \mathrm{~mm}$ in diameter and $120 \mathrm{~mm}$ high, fig. 2, which was heated through 4 heating elements placed in vertical holes drilled in the wall of the cylinder. A thermocouple recorded the temperature in the bottom of the bore. The temperature, was kept constant to within $1^{\circ} \mathrm{C}$ and the temperature readings seemed to be within $10^{\circ} \mathrm{C}$.

An isolating asbestos mantle was wrapped around the cylinder. In order to prevent undue heating of adjoining parts of the testing machine the cylinder was placed on a sheet of asbestos precompressed from $4 \mathrm{~mm}$ to $3 \mathrm{~mm}$. The reduction in strain sensitivity caused by this arrangement did not interfere with the main aim of the experiments: to show variations in strength and

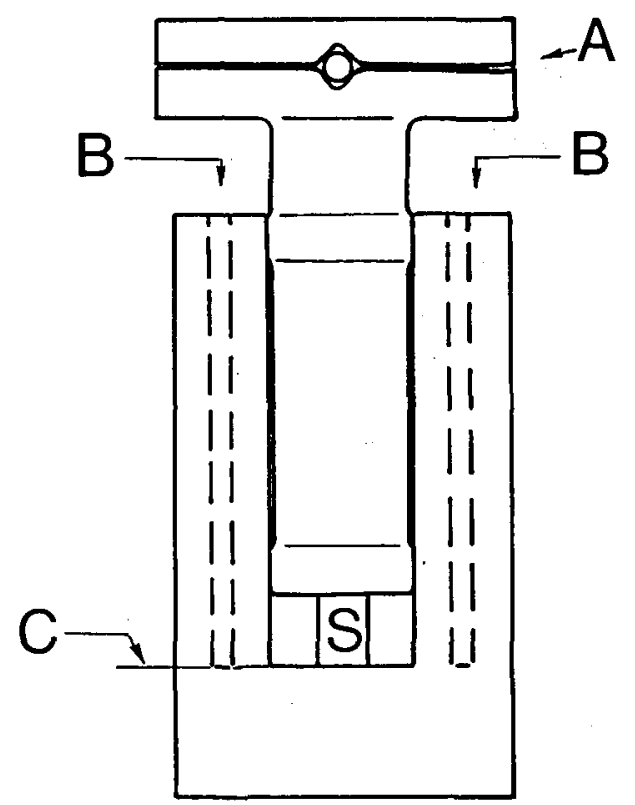

Fig. 2. Steel cylinder with piston for uniaxial compression tests at elevated temperatures. A: stecl-ball transfer of load to piston, B: electric heating elements, C: thermocouple for temperature control, S: sample.

ductility of cryolite with increase in temperature. Calibration of the set-up was obtained through tests on a steel prism of the same dimensions as the cryolite test samples. Evaluations of the recorded load-strain curves were moreover based on the measured ultimate lengths of samples recovered unbroken after tests. Table 3 summarizes the results obtained in a series performed in a 10ts Amsler Tensile Testing Machine with manual load control. Tables 4 and 5 give the results from

Table 3. Strength and stress-strain values for cryolite at $442-530^{\circ} \mathrm{C}$, tested in a 10 ts. Amsler Tensile Testing Machine. Strain rate, manually controlled, estimated to be around $1 / 4 \mathrm{~mm} / \mathrm{min}$. Strength and stress in bars.

\begin{tabular}{ccccccccccc}
\hline $\mathrm{T}^{\circ} \mathrm{C}$ & eyp & $1 \frac{\mathrm{l} / 2 \%}{5 \%}$ & $5 \%$ & $61 / 2 \%$ & $8 \%$ & $10 \%$ & $12 \%$ & $30 \%$ & $34 \%$ & $50 \%$ \\
\hline 442 & 500 & 600 & $665^{*}$ & - & - & - & - & - & - & - \\
450 & 380 & 443 & $(499)$ & - & - & - & - & - & - & - \\
460 & 360 & 428 & 485 & 490 & 504 & 504 & $506^{*}$ & - & - & - \\
470 & 325 & 389 & 404 & $397^{*}$ & - & - & - & - & - & - \\
480 & 200 & 305 & $361^{*}$ & - & - & - & - & - & - & - \\
490 & 190 & 286 & 337 & 346 & 350 & $*(351)$ & - & - & - & - \\
528 & 100 & 163 & 181 & 187 & 193 & 194 & 198 & 193 & 188 & 200 \\
530 & 60 & 103 & 133 & 140 & 147 & 153 & 158 & 154 & 149 & - \\
\hline
\end{tabular}

* indicates rupture of sample.

parentheses indicate extrapolated values.

eyp = estimated yield point, here taken as the strength or resistance to failure (Handin 1966). 


\section{Stress}

in bars

\section{0}

400

600

600

450

400

470
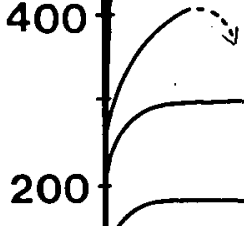

$0.5 \mathrm{~mm} / \mathrm{Min} \quad 480$

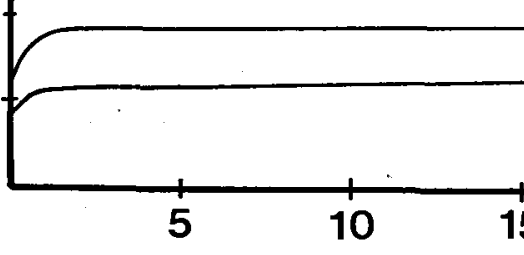

pression with strain rate $0.2 \mathrm{~mm} / \mathrm{min}$ in at temperatures from $400^{\circ}$ to $550^{\circ} \mathrm{C}$.

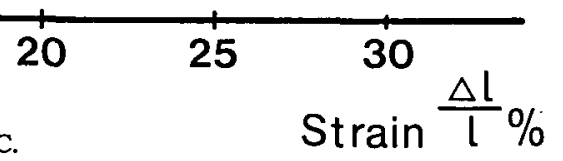

Table 4. Strength and stress-strain values for cryolite at $400-550^{\circ} \mathrm{C}$, tested in a 10 ts Instron Tensile Testing Machine. Strength and stress in bars.

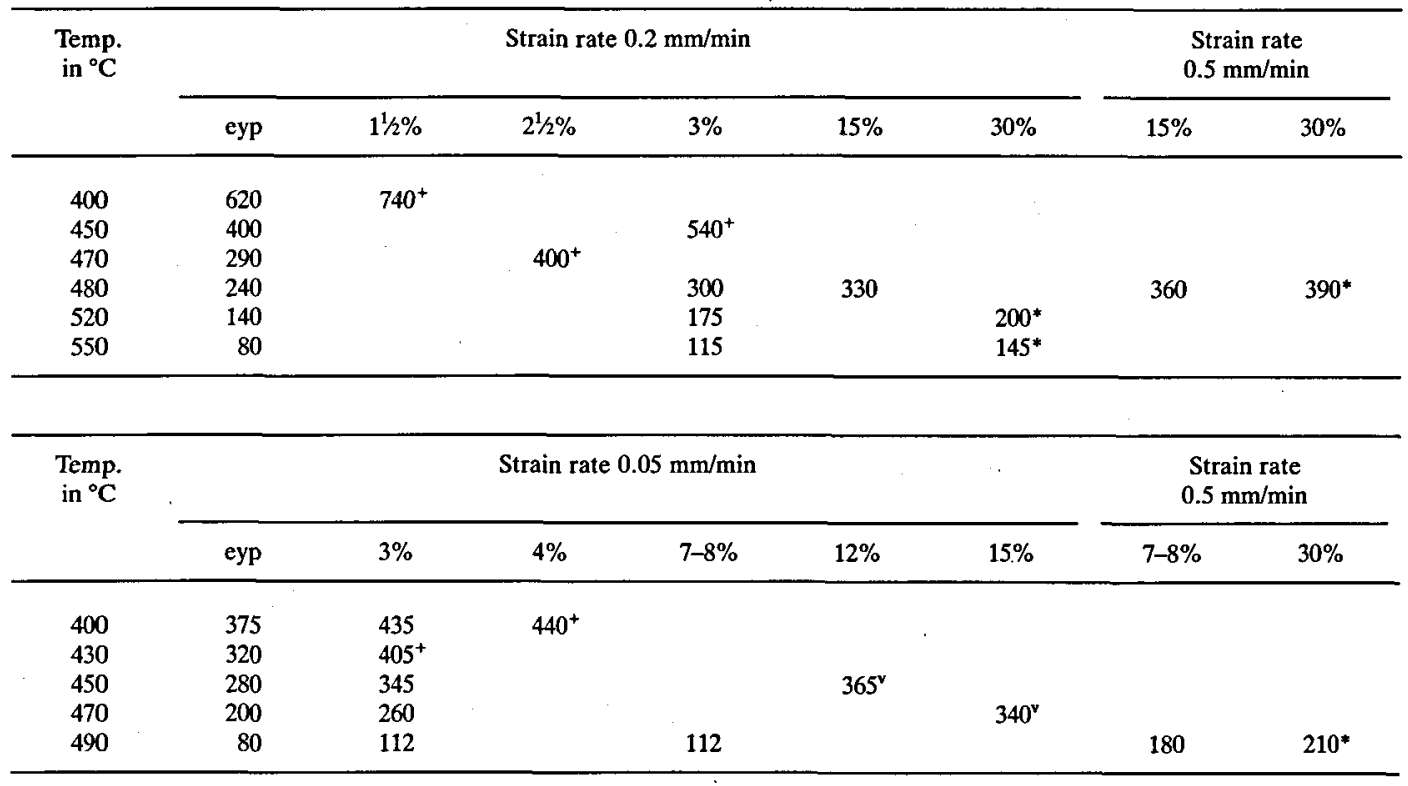

+ Hereafter sample deteriorated by spalling.

v Compression terminated.

* Compression continued.

NB: Note change in strain rate in test runs at 480 and $490^{\circ}$. 


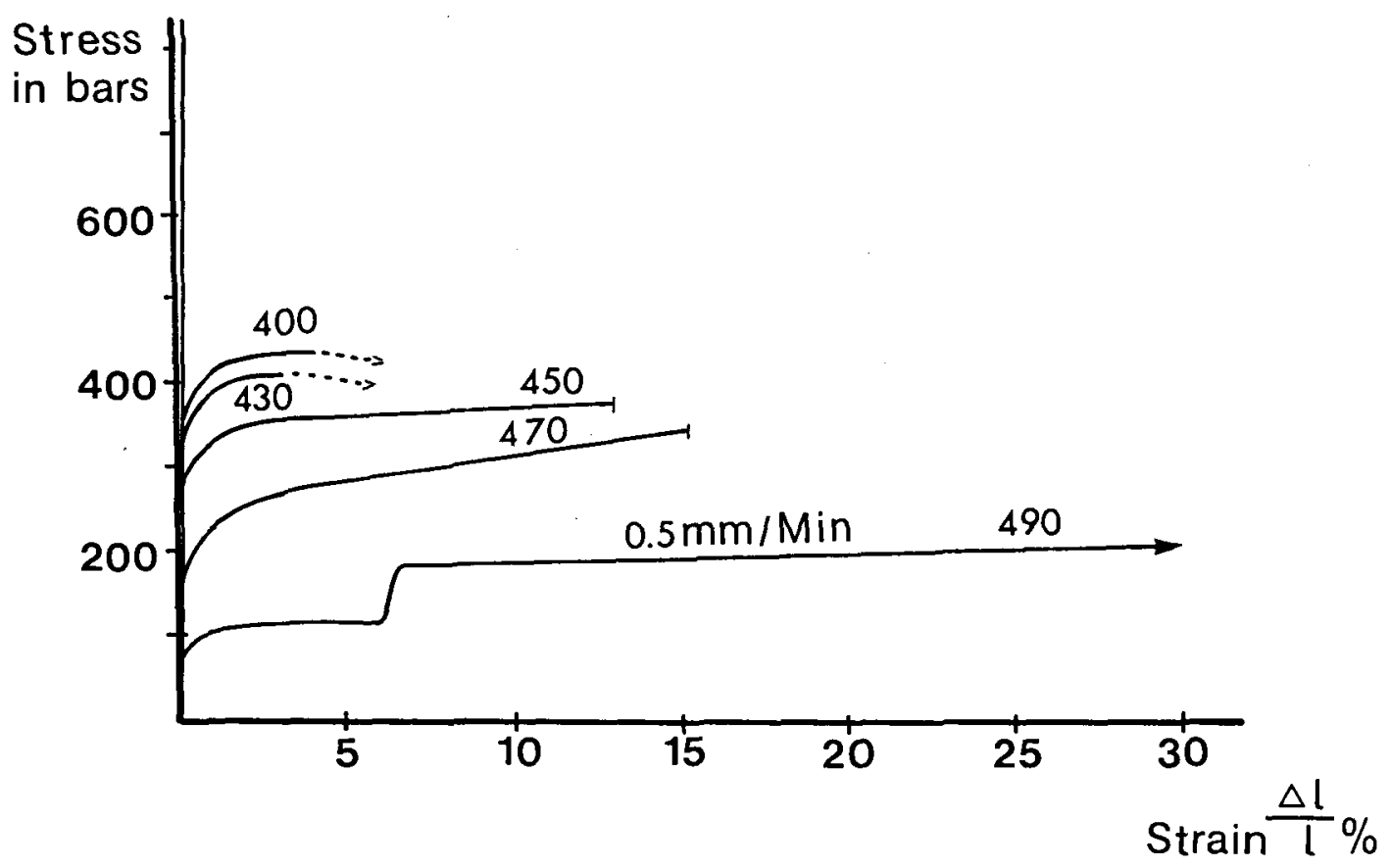

Fig. 4. Stress strain curves for cryolite from uniaxial compression with strain rate $0.05 \mathrm{~mm} / \mathrm{min}$ at temperatures $400^{\circ}$ to $490^{\circ} \mathrm{C}$.

tests in a 10-ts Instron Tensile Testing Machine with automatically controlled, constant strain rates. Figs. 3 and 4 show the stress strain curves obtained from the tests in this machines.

\section{Uniaxial compression of halite at temperatures from 100 to $400^{\circ} \mathrm{C}$ and atmospheric pressure}

For reference, test specimens were cut from a 6 $\mathrm{cm}$ cleavage piece of glass-clear halite from Grasleben, Helmstedt, Niedersachsen, Germany. The sides of the $15 \times 10 \times 10 \mathrm{~mm}$ prisms were cut parallel to the cleavage planes $(001)$ of the halite.

These samples were tested at 100,150, 200 and $400^{\circ} \mathrm{C}$ with the same procedure as was used for cryolite, in the 10-ts. Instron Tensile Testing Machine. Table 5 summarizes the obtained results and fig. 5 shows the corresponding stress-strain curves. The results seem to be broadly consistent with known data for halite e.g. such as reported by Heard 1972 . His experiments, carried out at 2000 bars confining pressure resulted in somewhat higher stress values than those observed in the uniaxial compression tests. The temperature influence, however, is much the same.

\section{Strength of cryolite up to $550^{\circ}$}

According to Handin 1966, strength is qualitatively defined as resistance to failure: continuing flow or fracture. As a measure for strength we here take the stress value recorded on the load strain curves at the point of fracture or the value estimated to correspond to the point where the curve starts to deflect from the straight line, the yield point e.y.p. as given in the tables 3 and 4 .

Table 5. Stress-strain values for halite at $100-400^{\circ} \mathrm{C}$, tested in a 10 ts. Instron Tensile Testing Machine. Strain rate 0.2 and italized values represent $0.5 \mathrm{~mm} / \mathrm{min}$. Stress in bars, strain in percents.

\begin{tabular}{lcccccc}
\hline $\begin{array}{l}\text { Temp. } \\
\text { in }{ }^{\circ} \mathrm{C}\end{array}$ & $5 \%$ & $10 \%$ & $12 \%$ & $16 \frac{1}{2} \%$ & $25 \%$ & $30 \%$ \\
\hline 100 & 130 & & 170185 & & 245 & \\
150 & 120 & 150 & 165 & 195 & 250 & 280 \\
200 & & 90 & & 110120 & & 145 \\
400 & 32 & & & & & 60 \\
\hline
\end{tabular}




\section{Stress}

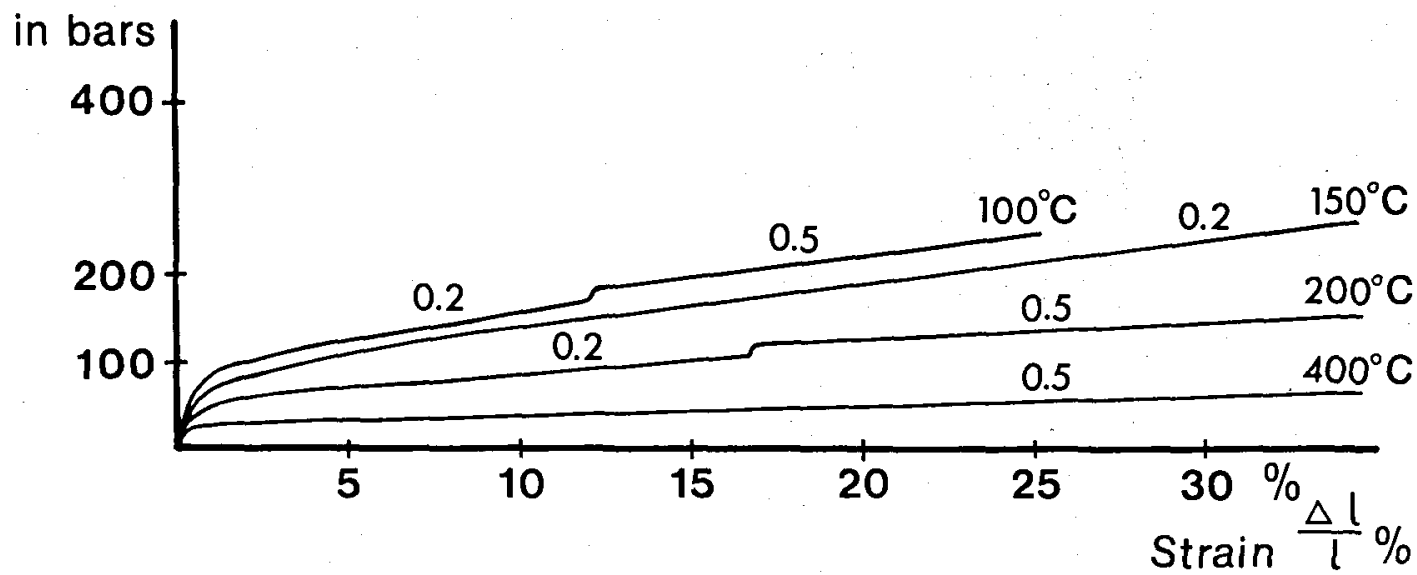

Fig. 5. Stress strain curves for halite from uniaxial compression, strain rates 0.2 and $0.5 \mathrm{~mm} / \mathrm{min}$ at temperatures from $100^{\circ}$ to $400^{\circ} \mathrm{C}$. Halite samples $15 \times 10 \times 10 \mathrm{~mm}$ cut from a $6 \mathrm{~cm}$ piece of a crystal from Grasleben, Helmstedt, Niedersachsen, Germany.

Cryolite tested at temperatures of $24^{\circ}, 100^{\circ}$, $200^{\circ}$ and $300^{\circ} \mathrm{C}$ gave stress strain curves which appeared as steeply rising, straight lines terminating with rupture of the samples. These curves were indistinguishable from curves obtained in runs where the test sample was a steel block of the same dimensions as the cryolite samples. Table 6 gives the maximum crushing strengths recorded in runs with strain rates 0.05 and $0.2 \mathrm{~mm} / \mathrm{min}$. The crushing strength obtained at room temperature is in keeping with the values obtained on the dm-sized samples, table 3 .

Whereas the maximum strength recorded at room temperature was 919 bars the tests at 100 , 200 and $300^{\circ} \mathrm{C}$ showed significantly increased strength values. At $200^{\circ} \mathrm{C}$ with a strain rate of $0.05 \mathrm{~mm} / \mathrm{min}$. a strength of 1360 bars was recorded. This increase might reflect destressing, at the higher temperatures, of microstress accumulations otherwise serving as starting points for fissure formation. Because samples allowed to

Table 6. Maximum crushing strength of cryolite in uniaxial compression tests.

\begin{tabular}{|c|c|c|}
\hline $\mathrm{T}^{\circ} \mathrm{C}$ & $\begin{array}{l}\text { Strain rate } \\
0.2 \mathrm{~mm} / \mathrm{min}\end{array}$ & $\begin{array}{c}\text { Strain rate } \\
0.05 \mathrm{~mm} / \mathrm{min}\end{array}$ \\
\hline 24 & 840 bars & 747 bars \\
\hline 100 & 1110 bars & 820 bars \\
\hline 200 & 1165 bars & 1360 bars \\
\hline 300 & 1000 bars & 1200 bars \\
\hline
\end{tabular}

cool after annealing at $300^{\circ} \mathrm{C}$ invariably showed low strengths between 600 and 900 bars, it is assumed that the destressing of micro-stress accumulations is active only while the higher temperature is maintained.

\section{Appearance of the samples after uniaxial compression}

The dm-sized samples, see tables 1 and 2, fractured parallel to the load axis, essentially along the parting directions of the cryolite. All the cmsized samples tested at temperatures up to $300^{\circ} \mathrm{C}$ were crushed to flakes and smaller particles; a clear picture of the fracture pattern could not be established.

The cm-sized cryolite samples tested at temperatures of $400^{\circ} \mathrm{C}$ and higher were recovered in full but reduced lengths more or less reduced in widths by spalling along planes parallel to the load axis, again reflecting the strong parting of cryolite.

Samples strained $12-15 \%$ showed bulging, see fig. 6. A number of fissures, tapering towards both ends, had developed parallel to the load axis. The compression of the samples was to a high degree brought about through bending of the lamellae into which the samples were split up. Samples strained to about half their length also showed this bending, but at the same time the 


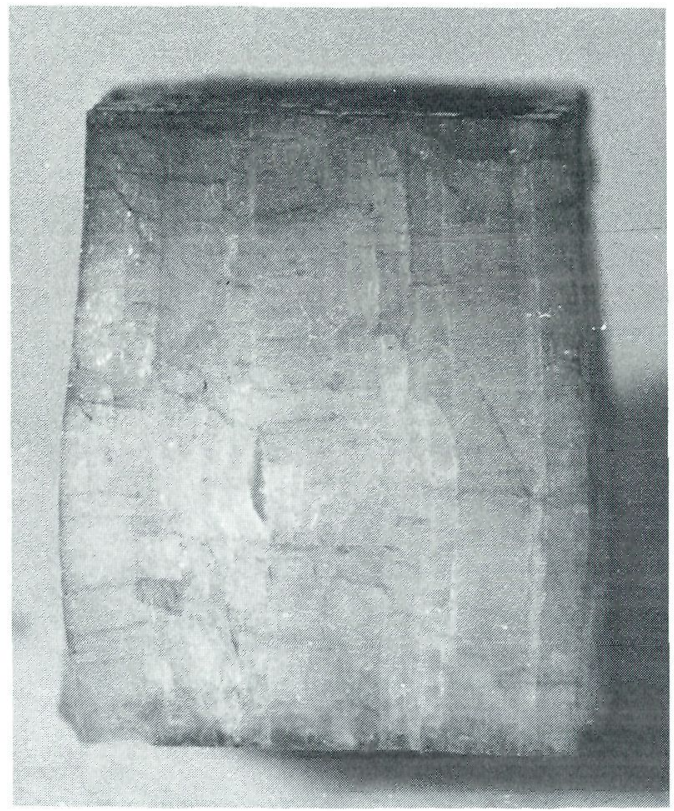

Fig. 6. Cryolite sample recovered after uniaxial compression $12-15 \%$ strained at $490^{\circ} \mathrm{C}$. Height of sample $13 \mathrm{~mm}$.

endfaces had increased up to $50 \%$ in area. In these cases bending as well as outwards flow seemed to have been active in the deformation of the samples. The sample tested at $480^{\circ} \mathrm{C}$, fig. 7 , developed a nearly horizontal wing to one side presumably due to partial spalling connected with the shift in strain rate from 0.2 to $0.5 \mathrm{~mm} /$ min., fig. 3. Rotation of the material at the root of the protruding wing concurrently with the proceeding deformation would explain its peculiar position.

The halite samples tested at temperatures from 100 to $400^{\circ} \mathrm{C}$ were all recovered in full but re- duced lengths but reduced in widths by spalling along planes parallel to the load axis reflecting the strong cleavage of the mineral after the cube faces. The compression of the samples took place, ás for cryolite at temperatures above $400^{\circ} \mathrm{C}$, through bending of the lamellae into which the samples were split up and as seen in fig. 7 , outwards flow played a substantial role in the deformation at $400^{\circ} \mathrm{C}$.

\section{Ductility of cryolite up to $550^{\circ} \mathrm{C}$}

All tests conducted at temperatures up to $300^{\circ} \mathrm{C}$ indicate that cryolite within the limits of the present experiments, is to be regarded as a perfectly brittle material for strain rates of $0.05 \mathrm{~mm} / \mathrm{min}$. and above. The remarkable stiffness of cryolite at these temperatures is not surprising in view of the multitude of polysynthetic twins present in the samples from Ivigtut. It seems probable that cryolite mainly deforms through twin gliding and these possibilities are obviously thoroughly exhausted following its earlier history in the deposit. At $400^{\circ} \mathrm{C}$ slight but recognisable plastic deformation took place before fracture in tests with a strain rate of $0.2 \mathrm{~mm} / \mathrm{min}$. Depending on strain rate cryolite was found to exhibit unrestricted plastic deformation at $450^{\circ} \mathrm{C}$ and higher temperatures. Above $400^{\circ} \mathrm{C}$ work hardening was moderate, and the deformation took place under stresses between 100 and 200 bars. The gradual disappearance of the twinning in cryolite observed by Yurk et al. 1973 is of particular interest because they noted this to take place between $470^{\circ}$ and $520^{\circ} \mathrm{C}$. This seems to underline the role of twin formation in the deformation of cryolite.

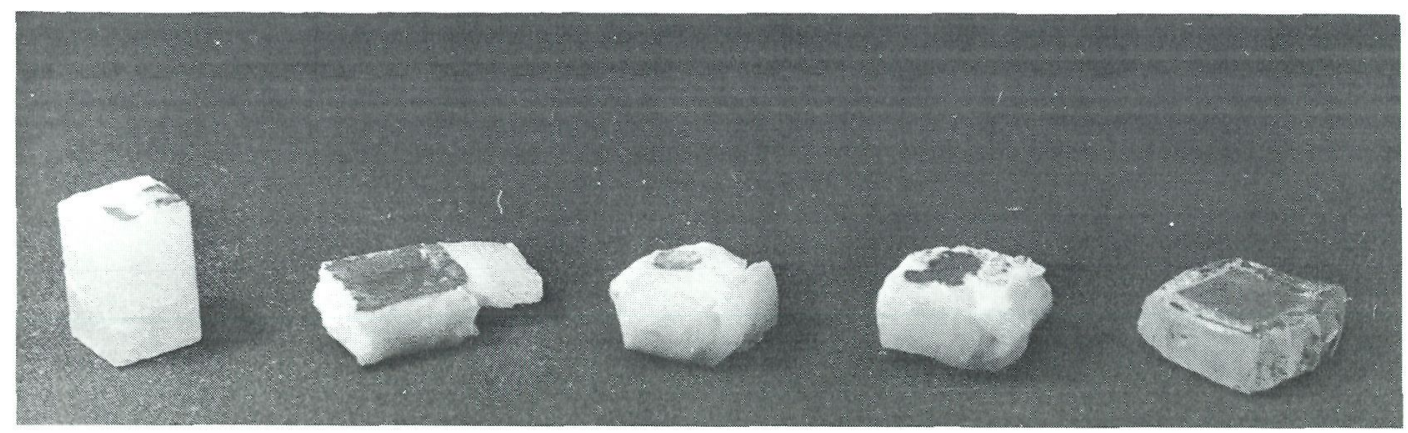

Fig. 7. Samples recovered after uniaxial compression: Cryolite $60 \%$ strained at $480^{\circ} \mathrm{C}, 40 \%$ at $520^{\circ} \mathrm{C}$ and $41 \%$ at $550^{\circ} \mathrm{C}$; halite $63 \%$ at $400^{\circ} \mathrm{C}$. To the left an undeformed sample of cryolite $15 \times 10 \times 10 \mathrm{~mm}$. 
The compression tests on halite showed this mineral to be ductile and capable of unrestricted plastic deformation already at temperatures around $100^{\circ} \mathrm{C}$. At $150^{\circ}$ to $200^{\circ} \mathrm{C}$ it deformed about as easily as cryolite at temperatures around $500^{\circ} \mathrm{C}$.

According to Phillips 1961 fluorite shows appreciable ductility above $400^{\circ} \mathrm{C}$ but the results reported seem to indicate that fluorite only become comparable to cryolite (at about $500^{\circ} \mathrm{C}$ ) when fluorite is heated to temperatures above $600^{\circ}$ up to $800^{\circ} \mathrm{C}$. The compression tests on fluorite were performed with strain rate $0.02 \mathrm{in} . / \mathrm{min}$. corresponding to about $0.4 \mathrm{~mm} / \mathrm{min}$.

\section{Implications for the interpretation of the development of the Ivigtut cryolite deposit}

\section{Ductility of cryolite}

In as much as the main part of the cryolite deposit consolidated at temperatures between 500 and $600^{\circ} \mathrm{C}$ the highly ductile behavior of cryolite observed in the tests at 490 to $550^{\circ} \mathrm{C}$ becomes of major importance in unravelling the development of the deposit, especially the mutual relations between the minerals, and the rocks building up and enclosing the deposit.

Pauly 1982 suggested plastic flow of cryolite to have introduced pure cryolite as a cement for rock xenoliths in the breccias along the border between the deposit and the rocks of the intrusion enclosing it. According to the results of the compression tests, this should have taken place at rather elevated temperatures, i.e. early in the formation of the deposit. Confining pressure enhances ductility, Handin 1966, and would allow for an extension of the temperature interval to lower values permitting these phenomenas to take place also in the later stages of the development of the deposits. Further parameters such as geological setting, temperature-indicating parageneses etc. are needed in order to establish the stage at which a particular breccia formation arose.

The siderite-cryolite itself seems to present the most convincing illustrations of the influence of the high ductility of cryolite at elevated temper-

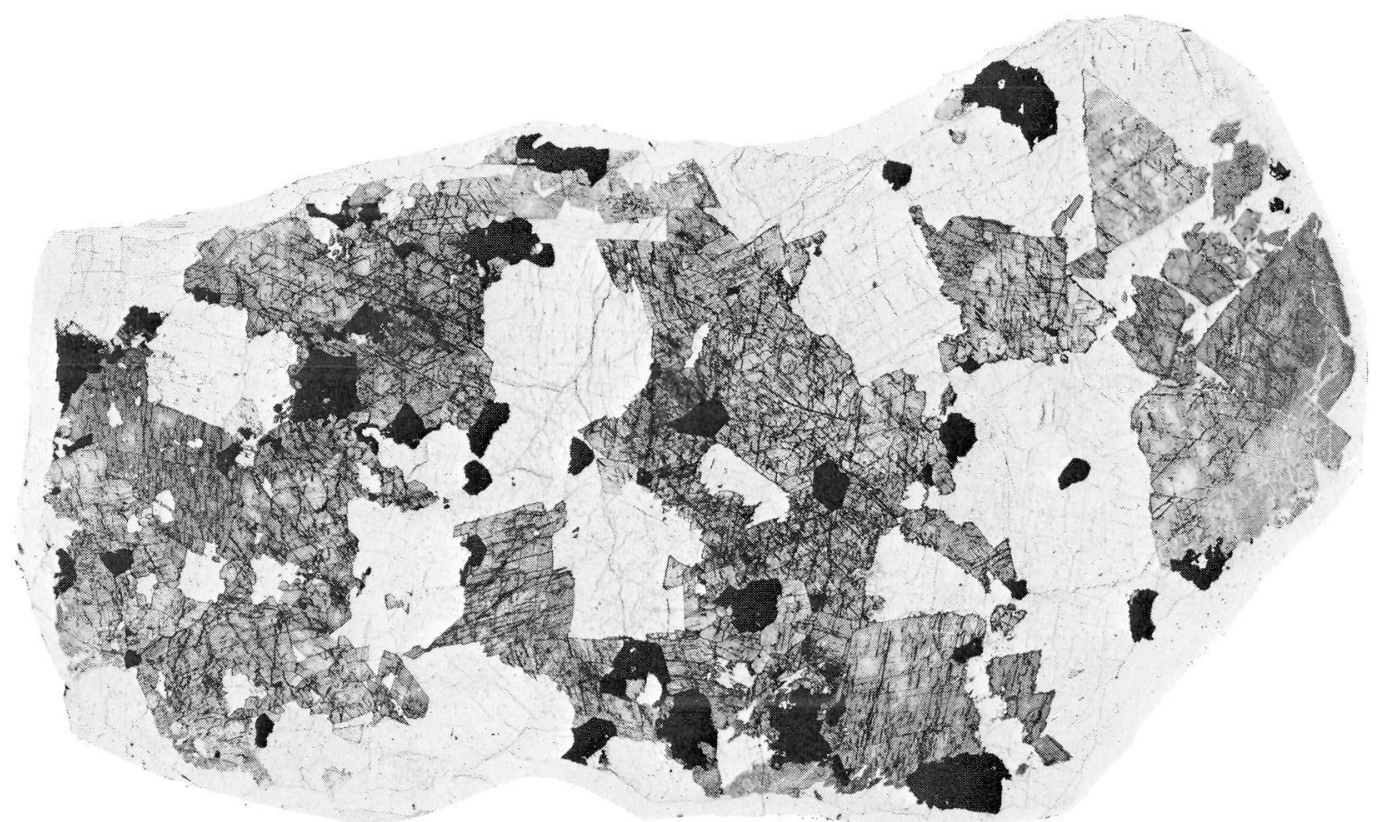

Fig. 8. Thin section of siderite cryolite, $14.5 \mathrm{~cm}$ across, plane light. Cryolite, colourless with shrinking fissures. Siderite greyish, with abundant cleavage fissures accentuated by limonite films. Shapes of siderite grains mainly determined by the cleavage. Shattering of siderite particularly well developed in the right hand side. Black, opaque grains are sulphides, here mainly chalcopyrite. 
atures. Fig. 8 shows a thin section of this material. Although the concentration of siderite is larger than average, it can be seen that siderite and sulphides are placed between more or less rounded areas of cryolite. This reflects the general texture of this material where cryolite occupies the masks of a three dimensional network formed of siderite with sulphides, Pauly 1960.

The excellent cleavage of siderite very clearly brings out the cataclastic structure of the material. Such a picture seems to be what would be expected if cryolite with siderite dispersed throughout the mass had been in a state comparable to a dough being thoroughly kneaded.

Although the straight-lined cleavage-induced borders between cryolite and siderite dominate as fig. 8 shows, one can here and there in thin sections also observe smooth, or slightly serrate, curving border lines between the two minerals. Smaller grains of cryolite wholly included within single individuals of siderite usually shows such border relations. These features are regarded as relics from a stage where siderite consolidated within a viscous mass of cryolite.

This took place above $500^{\circ} \mathrm{C}$ and means that the assemblage existed under conditions where the ductility of cryolite is very high and the material would be expected to yield in response to even fairly small stress differences.

Between the units of the deposit - the sideritecryolite, the fluorite-cryolite and the intercalated body of pure cryolite - the borders were characterised by brecciations, veins and protuberances of pure cryolite. In some parts of the cryolite quarry large structures have been observed which seem to indicate relative movements between the units, involving disruption and injection of cryolite in between displaced parts of the involved units. These phenomena lend themself to an interpretation related to the high ductility of cryolite.

\section{Brecciation of cryolite in the deposit}

Shattering or brecciation of cryolite has been observed in various parts of the deposit. Cryolite originally cementing rock xenoliths in a breccia has been found thoroughly shattered and cemented by narrow veins filled by fine-grained mica and small grains of cryolite (Pauly 1982).
Similar masses of shattered cryolite have also been observed within the deposit in certain parts of the fluorite-cryolite. In these cases it is clear that cryolite has behaved as a brittle material.

As no bending of cryolite fragments was observed the crushing may have taken place at low temperatures where yielding was inconspicuous or, alternatively, strain rates may have been high as might be the case if sudden changes took place within the deposit.

\section{Contraction on cooling of cryolite}

As long as cryolite behave reasonably plastically its contraction on cooling may have resulted in a shrinking away of the whole deposit from, probably, the upper border to the rocks of the intrusion. The linear contraction on cooling down to $300^{\circ} \mathrm{C}$ is about $1.5 \%$ and would account for about $3 \mathrm{~m}$ reduction in height of the deposit simultaneous with lateral plastic displacement of its materials. This would most probably also affect the overlying rocks.

At lower temperatures where plasticity of cryolite becomes insignificant, macrofissures and microfissures may have developed both in cryolite and in the accompanying minerals. Meterlong vertical fissures observed at various times in the exposed walls of the quarry may have originated in this way. Filled with secondary minerals, in particular with prosopite, thomsenolite etc., they have served as depositories for late, mineralising fluids. Shattered fragments of cryolite embedded in the masses of the secondary minerals (unpublished observation by the late $\mathrm{R}$. Bøgvad) indicate movements in a state where cryolite behaved as a brittle material. Also the open fissure between the deposit and the hanging wall, observed already in 1867 by Søren Fritz (unpublished report) may have its origin in the contraction on cooling of the cryolite mass.

The microfissures in siderite stand out in thin sections, see fig. 8 , due to the presence of limonitic films (Steenstrup 1910). These microfissures are probably in part caused by the contraction of the cryolite. The formation of the iron oxide may be the result of disintegration and degassing of the ironcarbonate at higher temperatures. Oxidation of ferrous to ferric iron may be of much later origin. 
It should appear from this brief account that ductility of cryolite may have played a prominent role in the development of the deposit. Primary structures may have become masked if not obliterated and many phenomena may be difficult to understand unless plastic flow of cryolite is taken into account.

The contraction on cooling of the mineral, contrasting markedly with the contractions of the associated minerals and rocks seems of interest both for the study of joint formations comeprising the whole intrusion and for detailed studies of macro- and microfissures within the deposit.

Acknoiwledgments. Mr. Ib H. Nielsen, Mineralogical Institut, The Technical University of Denmark, prepared the samples, constructed the steelcylinder for experiments at elevated temperatures and executed the compression tests. His careful work and never failing interest are gratefully acknowledged. Mr. Frantz Olfert, The Department for Mechanical Technology, The Technical University of Denmark, is warmly thanked for his assistance in planning and executing the initial work. It is a pleasure to bring my best thanks to Mr. Torben Kjer at the Metallurgical Department of The Technical University of Denmark, for his interest in this work and the inspiring discussion he engaged in. Dr. J. Bailey is thanked for his perusal of the manuscript, his suggestions have improved the English of the manuscript considerably.

\section{Dansk sammendrag}

Kryolit udgjorde $3 / 4$ af forekomsten i Ivigtut, S-Grønland. Dets mekaniske egenskaber anses for at have været af betydning for sảvel formen som den indre opbygning af forekomsten hvis hovedpart - jernspat-kryolit, med ca. $15 \%$ jernspat og et par \% kvarts, sulfider etc., dannedes mellem 500 og $600^{\circ} \mathrm{C}$.

Kryolits rumfangsudvidelse ved opvarmning er fundet at være 2 til 5 gange større end de ledsagende mineraler og bjergarters varmeudvidelse.

Kryolits elastiske konstanter er bestemt til: $\mathrm{E}=6.8 \cdot 10^{5}$ bar, $\mathrm{G}=2.7 \cdot 10^{5}$ bar og Poissons forhold er 0.24 . Kryolits brudstyrke ved stuetemperatur er ved enaxede trykfors $\emptyset \mathrm{g}$ på prismer, $15-20 \mathrm{~cm}$ lange med kvadratiske tvarsnit på fra $4-9 \mathrm{~cm}$ kantlangde, fundet at vare op til 919 bar.

Ved enaxede trykfors $\emptyset \mathrm{g}$ ved atmosfæretryk, på $1,5 \mathrm{~cm}$ lange prismer med kvadratisk tvarsnit på $1 \mathrm{~cm}^{2}$, er observeret brudstyrker op til 1360 bar ved $200^{\circ} \mathrm{C}$ med $0.05 \mathrm{~mm}$ sammentrykning pr. minut. I alle fors $ø \mathrm{~g}$ op til $300^{\circ} \mathrm{C}$ viste kryolit en retlinet arbejdskurve indtil brud dvs. mineralet viste sig fuldstændigt sprødt. Ved $400^{\circ} \mathrm{C} \mathrm{og} \mathrm{højere} \mathrm{temperaturer} \mathrm{iagttoges} \mathrm{plastisk} \mathrm{de-}$ formation. Afhængig af sammentrykningshastigheden viste kryolit ubegrænset plastisk deformation over $450^{\circ} \mathrm{C}$. Kryolits plasticitet ved temperaturer omkring $500^{\circ} \mathrm{C}$ var nogenlunde som stensalts prøvet på samme måde ved temperaturer på 150$200^{\circ} \mathrm{C}$.

Det må bemærkes at den plastiske deformation i disse enaxede trykforsøg især giver sig til kende som bøjning af lameller parallelle med trykretningen, men nogen horisontal forskydning iagttoges også. Dette galder såvel den undersøgte kryolit som den undersøgte stensalt.

Jernspat $i$ jernspat-kryolit viser altid en udpræget opknust, kataklastisk struktur. Dette fremhæves af jernspats udprægede spaltelighed. Denne opknusning tilskrives mekaniske pávirkninger af forekomsten ved høje temperaturer hvor kryolit med de deri indlejrede andre mineraler, takket være sin udpragede plasticitet, har opført sig som en dejg der æltes. Primære strukturer i denne del af kryolitmassen er formentlig vidtgående forsvundet ved den plastiske deformation af massen.

Formen af kryolitlegemet, en affladet dråbeform, tilskrives også den plastiske deformation af legemet. Breccieret og opknust kryolit kan være udtryk for mekaniske påvirkninger ved lave temperaturer hvor kryolit fandtes at opføre sig som et sprødt materiale, men disse dannelser kan også skyldes meget hurtige trykpåvirkninger under hvilke mineralet ikke har kunnet nå at reagere ved plastisk flydning.

Kryolits varmeudvidelse, eller her rettere sammentrakning under afk $\varnothing$ ling, der er 2-5 gange større end den de indesluttede og de omgivende mineraler og bjergarter viser, anses for vigtig for forståelsen af både makro- og mikrorevner i forekomsten, blandt andet den sine steder åbne flækkegrænse kryoliten viste mod den omgivende granit.

\section{References}

Bailey, J. C. 1980: Formation of cryolite and other aluminofluorides: A petrologic review. Bull. geol. Soc. Denmark, 29: $1-46$.

Bøggild, O. B. 1905: Mineralogia Groenlandica. Medd. om Grønland XXXII: 108-115.

Bøggild, O. B. 1912: Krystallform und Zwillingsbildungen des Kryoliths, des Perowskits und des Boracits. Zeitschrift Krystallogr. 50: 349-429.

Donnay, J. D. H. 1952: Cryolite Twinning. Am. Min. 37: 230234.

Handin, J. 1966: Strength and Ductility. Section 11 in: Handbook of Physical Constants - Revised Edition, Geol. Soc. of America Memoir 97: 223-235.

Hawthorne, F. C. and Ferguson, R. B. 1975: Refinement of the crystal structure of cryolite. Canadian Mineralogist 13: 377-382.

Heard, H. C. 1972: Steady - State Flow in Polycrystalline Halite at 2 kilobars. (Heard et al. eds.), American Geophysical Union Monograph 16: 191-209.

Holm, J. L. 1965: Phase Transitions and Structure of the High Temperature Phases of some Compounts of the Cryolite Family. Acta Chemica Scandinavica 19: 261-263.

Holm, J. L. and Jenssen Holm, B. 1970: Phase Investigations in the System $\mathrm{Na}_{3} \mathrm{AlF}_{6}-\mathrm{Li}_{3} \mathrm{~A}_{1 \mathrm{~F}}$. Acta Chemica Scandinavica 24: 2535-2545.

Karup-Møller, S. 1973: A gustavite-cosalite-galena bearing mineral suite from the cryolite deposit at Ivigtut, South Greenland. Medd. om Grønland, 195, 5: 40.

Karup-Møller, S. and Pauly, H. 1979: Galena and associated ore minerals from the cryolite at Ivigtut, South Greenland. Medd. om Gronland, Geoscience 2: 1-25.

Landon, G. J. and Ubbelohde, A. R. 1956: Volume changes on melting of ionic crystals. Trans. Faraday Soc. 52: 647-651.

Landon, G. J. and Ubbelohde, A. R. 1957: Melting and crystal structure of cryolite $\left(3 \mathrm{NaF}, \mathrm{A1F}_{3}\right)$. Proceedings of the Royal Society, A, 240: 160-172.

Mügge, O. 1908: Über einige Demonstrationsversuche an Leucit, Kryolit, Perowskit, Gadolinit, Quartz und Quartzglas mit dem Lehmann'schen Erhitzungsmikroskop. Centralblatt für Mineralogie 34-38.

Oen, I. S. and Pauly, H. 1967: A sulphide paragenesis with pyrrhotite and marcasite in the siderite-cryolite ore of Ivigtut, South Greenland. Medd. om Grønland 175, 5: 1-56.

Palache, C., Berman, H. and Frondel, C. 1951: Dana's system of Mineralogy, Seventh Edition, Aluminofluorides, 110128 
Pauly, H. 1960: Paragenetic relations in the main cryolite ore of Ivigtut, South Greenland. Neues Jb. Miner. Abh. Festband Ramdohr, 94: 121-139.

Pauly, H. 1962: Sort og hvidt [violet] kryolit fra Ivigtut. Meddr. dansk geol. Foren. 15: 145.

Pauly, H. 1978: Twins in cryolite types from Ivigtut, South Greenland. Bull. geol. Soc. of Denmark, 27: 7-14.

Pauly, H. 1982: Plasticity of cryolite and brecciation in the cryolite deposit, Ivigtut, South Greenland. In: Ore Genesis, The State of the Art, ed. by G. C. Amstutz, A. El. Goresy etc. Special Publication No. 2 of the Soc. for Geology Applied to Mineral Deposits, 345-350.

Phillips Jr., W. L. 1961: Deformation and fracture processes in calcium fluoride single crystals. Journal of the American Ceramic Society, 44, 10: 499-506.

Pickett, G. 1945: Equations for computing elastic constants from flexural and torsional resonant frequencies of vibra- tion of prism and cylinders. Proc. Am. Soc. Testing Materials, 45: 846-865.

Skinner, B. J. 1966: Thermal Expansion, Section 6 in: Handbook of Physical Constants. Geol. Soc. of America, Memoir, 97: 75-96.

Steenstrup, K. J. V. 1911: Om jærnspaten i kryoliten ved Ivigtut. Medd. om Grønland, XLVII: 383-387.

Steward, E. G. and Rooksby, H. P. 1953: Transitions in crystal structure of cryolite and related fluorides. Acta Cryst. 6: 49-52.

Wrinch, D. 1952: Twinning of Cryolite. Am. Min. 37: 234-241.

Yurk, Yu. U., Buruv, E. P. and Gurova, E. P. 1973: Genesis of cryolite in metasomatic rocks of the Ukrainian shield. Dokl. Acad. Sci. U.S.S.R., Earth Sci. Sect. 208: 143-145 (in Russian) (from Mineral. Abstr. 1980. vol. 31, No. 3, $80-3520$, p. 355). 